\title{
A survey of definitions of small business in the southern african context
}

\author{
A.P. du Plessis* and C. Boshoff \\ Department of Business Economics, Vista University, Private Bag X613, Port Elizabeth, 6000 Republic of South Africa \\ P.L. Moolman \\ Small Business Advisory Bureau, PU For CHE, Potchefstroom, 2520 Republic of South Africa
}

\author{
G. Radder
}

Department of Accountancy, Vista University, Private Bag X613, Port Elizabeth, 6000 Republic of South Africa

Received 16 September 1988; accepted 3 October 1988

\begin{abstract}
This paper reports on a survey of the definition of small business as perceived by various organizations involved in small business training and development. Participants were requested to define small business in terms of quantitative as well as qualitative criteria. The definitions provided by the survey respondents werc compared with published definitions of small business as formulated by the Small Business Development Corporation (SBDC), the National Manpower Commission (NMC), J.G. Smith (one of the first authors who attempted to define small business), and the Small Business Advisory Bureau (SBAB). The definitions suggested by respondents indicate a lack of definitional consensus. Although no specific definition is suggested here, it is hoped that the information provided and the interpretation thereof may stimulate and encourage efforts to formulate a simple, useful, and widely accepted definition of small business in southern Africa.
\end{abstract}

\begin{abstract}
Hierdie artikel doen verslag oor 'n ondersoek na die definisie van kleinsake, soos deur verskeie organisasies wat by kleinsake-opleiding en -ontwikkeling betrokke is, omskryf word. Respondente is versoek om 'n kleinsaak volgens kwantitatiewe en kwalitatiewe riglyne te definieer. Die definisies van die respondente verkry, is ook met gepubliseerde kleinsakedefinisies van die Kleinsake-Ontwikkelingskorporasie (KSOK), die Nasionale Mannekragkommissie (NMK), J.G. Smith (een van die eerste persone wat gepoog het om 'n kleinsaak te definieer), en die Adviesburo vir Kleinsakeondernemings (ABKS) vergelyk. Geen spesifieke definisie word deur die outeurs voorgestel nie, maar hopelik sal die inligting en interpretasiepogings meehelp om 'n eenvoudige, bruikbare, en algemeen aanvaarbare definisie van 'n kleinsaak in Suider Afrika te formuleer.
\end{abstract}

* To whom correspondence should be addressed

\section{Introduction}

A new era in the promotion of small business in southern Africa was heralded by the so-called Carlton Conference in Johannesburg in 1979 and the Good Hope Conference in 1981. These Conferences demonstrated a new spirit concerning small business.

Since then and with the publication of the South African President's Council report in 1985 on a suggested strategy for small business development and for deregulation (President's Council, 1985), as well as the acceptance by Government of the recommendations contained in the report (de Villiers, 1986), much has been said and published on small business development in southern Africa. However, in attempting to assess the importance of modern small business in any country, and particularly the informal business sector in southern Africa, the problem of definition is of paramount importance, particularly where a major component of the population has a high potential for small business development. Opinions differ on the exact definition of a small business. Differences in interpretation of the concept 'small business' are encountered not only between countries, but also within the same country (Moolman, 1987).

Two further aspects complicate the matter of a proper definition as far as southern Africa is concerned. Firstly, southern Africa is a developing African region, where a distinction is implied between the formal and the informal sector. The question could be posed: Where does the informal sector fit in? The informal sector can generally be regarded as that part of the country's economic activities that is not recorded in the national accounts, in other words the statistically unrecorded activities (National Manpower Commission, 1984: 8). As the distinction between the two sectors is strongly emphasized by some, it could be argued that separate definitions for both should be maintained if the scope for estimating the size and importance of the two sectors is to be broadened. The informal sector in southern Africa is at present regarded as part of the small business sector.

A second complicating factor in formulating a suitable definition for small business is that neither the original Council for the Promotion of Small Business (CPSB), which was established in 1982, nor the Council for Small Business (CSB), which replaced this body in 1986, has provided an official definition of what is meant by 'small business'.

The CPSB did request the Small Business Advisory Bureau (SBAB) to attempt to formulate a universally acceptable definition which could be applied by all the subsidized institutions involved in the training and development of small business. The Small Business Development Corporation (SBDC), also being subsidized, however, insisted on an unique definition. In view of the unique and specialized service in the field of 
financial services and infrastructure creation, this suggestion was accepted by the other subsidized institutions. This definition, formulated for application by the institutions, was accepted by the CPSB and later acknowledged by the newly formed CSB.

According to Bulloch \& Hertz (1982: 2) the need for a standardized international definition of small business is not always realized and accepted. According to these authors '...... a phenomenon without an exclusive definition is a non-existent phenomenon. It cannot ask for, nor expect special consideration'.

Moolman \& Pretorius (1987: 2-3) also emphasized the need for a standardized definition of small business in a southern Africa context. According to the authors some view the need for such a definition as only of academic interest and not a practical requirement. This is a very myopic approach. The following reasons are quoted by Moolman \& Pretorius (1987: 2-3) why a uniformly acceptable definition could enhance small business development:

1. a standardized definition is necessary to measure the state and role of small business in the economy of the country. It is difficult to quantify the contribution of small business to the economy, partly because small business is ill-defined;

2. a definition is imperative for development policy purposes, especially in the southern African context, which is characterized by a dualistic economic situation, with an under-developed Third World element and a well-developed First World element;

3. the role of the small business sector in the economy is of such significance that it should be clearly defined in order to measure performance against pre-set objectives;

4. an exclusive definition is imperative, not only from a juridical prospective but also from a factual one;

5. an internationally acceptable small business definition will allow greater international co-operation in the development of measures to deal with the problems and opportunities that are unique to the small business sector;

6. size standards determine which firms are eligible for public and private assistance in such areas as loans, loan guarantees, management consultation and training services and equity financing; and

7. development organizations are serving medium or even large businesses as well as small businesses. If the widely touted public distrust of 'big business' is taken into account, either the public or the development organizations need to be 'educated' as to what constitutes small business. Unless a definition of small business that is mutually acceptable to the public and these development organizations is developed, public support for the latter is likely to dwindle.

\section{Problem definition}

When attempting to define small business an important consideration is that various organizations, both public and private, offer a wide variety of services to small businesses. These services include financial assistance, the creation of infrastructure, training in various fields, and advice on initiating and operating a small business. If it is assumed that these organizations are playing, and will continue to play, a vital role in the development of small businesses, and in the possible formulation of macro-economic policy, then it is essential that some degree of consensus should be reached on what a small business constitutes. If further effective discussion of small business is to occur at macro-economic policy level, there should be an understanding of what the term really means to those organizations directly involved in small business development. This paper presents the findings of a survey designed to document the definition of small business as perceived by those organizations directly involved in small business training, financing, infrastructure creation, and advisory services.

\section{Method}

Questionnaires were mailed to all 78 training and development organizations listed in the Small Business Training Directory (SBDC: 1987) which is compiled annually by the Small Business Development Corporation Training Services. Completed questionnaires were returned by 27 organizations. Five organizations returned their questionnaires with an explanation of why these could not be completed. One questionnaire returned indicated that the respondent was no longer involved in small business development and could therefore not be used. Three questionnaires were received after the due date and could not be included in the survey results.

The contents of $34,6 \%$ of the total number of questionnaires mailed were thus used for the purpose of this paper.

The respondents were requested to express their opinion regarding two quantitative criteria for defining a small business, namely: the maximum number of employees in a business to be regarded as a small business and the maximum annual turnover (sales) that a business may have and still be regarded as a small business. Respondents were also asked to provide their own definition of a small business.

\section{Results}

\section{Number of employees}

Of the 27 respondents, only 24 gave an indication of what they regarded as the maximum number of employees. The results are presented in Table 1 and shows that $26,9 \%$ of the respondents were of the opinion that a small business could have more than 50 employees and $29,6 \%$ of the respondents felt that the category $26-$ 50 employees is more appropriate. It is nevertheless interesting to note that the range of responses was 2 100; the median number was 50 ; and the mean was 51,9 . The modal response was 100 employees.

\section{Sales volume}

Table 2 reveals the distribution of responses to the question regarding 'Maximum sales volume'. The 
Table 1 Maximum number of employees for business to be considered 'small'

\begin{tabular}{lccc}
\hline & \multicolumn{3}{c}{ Response } \\
\cline { 2 - 4 } $\begin{array}{l}\text { Maximum Number } \\
\text { of employees }\end{array}$ & Number & $\begin{array}{c}\text { Absolute } \\
\text { percentage }\end{array}$ & $\begin{array}{c}\text { Cumulative } \\
\text { percentage }\end{array}$ \\
\hline 5 or less & 2 & 7,4 & 7,4 \\
$6-10$ & 2 & 7,4 & 14,8 \\
$11-25$ & 4 & 14,9 & 29,7 \\
$26-50$ & 8 & 29,6 & 59,3 \\
$51-100$ & 8 & 29,6 & 88,9 \\
No response & 3 & 11,1 & 100,0 \\
& 27 & 100,0 & \\
\hline
\end{tabular}

Table 2 Maximum annual sales volume for businesses to be considered small

\begin{tabular}{lcc}
\hline & \multicolumn{2}{c}{ Response } \\
\cline { 2 - 3 } Sales volume & Number & Percentage \\
\hline Less than R100 000 & 1 & 3,7 \\
$100000-250000$ & 5 & 18,5 \\
$250001-500000$ & 2 & 7,4 \\
$260001-1000000$ & 5 & 18,5 \\
More than R1 000 000 & 8 & 29,7 \\
No response & 6 & 22,2 \\
& 27 & 100,0 \\
\hline
\end{tabular}

Table 3 Major dimensions of suggested small business definitions

\begin{tabular}{lcc}
\hline & \multicolumn{2}{c}{ Response } \\
\cline { 2 - 3 } Dimensions & Number & Percentage \\
\hline Privately and independently owned, & & \\
$\quad$ managed and operated & 15 & 60,0 \\
Limited number of employees & 13 & 52,0 \\
Limited turnover (sales) & 10 & 40,0 \\
Limited value of assets & 9 & 36,0 \\
Limited number of operating units & 4 & 16,0 \\
Simple organizational structure & 3 & 12,0 \\
Geographically restricted & 3 & 12,0 \\
Small influence on total market & 2 & 8,0 \\
Limited electrical power usage & 2 & 8,0 \\
\hline
\end{tabular}

responses ranged from 'no response' to ' $R 10$ million'.

From Table 2 it is apparent that the value of the sales of a business may be higher than R1 000000 and still be regarded as a small business, according to $29,7 \%$ of respondents. Three of the eight respondents who indicated sales greater than R1 000000 mentioned a maximum annual turnover of R5 000000 , while one respondent indicated an annual turnover of R10 000000 .

\section{Proposed small business definitions}

A contents analysis was performed on the definitions of a small business provided by 25 of the 27 respondents. The contents analysis was based on the nine dimensions listed in Table 3.

The most frequently mentioned dimension of a small business was "privately and independently owned, managed and operated'. This dimension was included in $60 \%$ of the 25 definitions used in the contents analysis. The next most commonly mentioned dimension was that a small business must have a limited number of employees, while 'limited turnover' and 'limited value of assets' respectively occupied the third and fourth positions.

\section{A comparison of survey results and previously suggested definitions}

One of the objectives of the survey was to compare the dimensions of definitions suggested by respondents with those suggested by Smith (1978: 46), the SBAB, the SBDC (1984: 7-9), and the NMC (1984: 6-9). These definitions are possibly the most representative of what a definition of small business in southern Africa should be.

According to the NMC the small business sector comprises formal and informal businesses and for this reason their formal and informal definitions are used, while the SBAB regards the informal sector as part of the small business sector, and has formulated a separate definition for the so-called micro businesses. The definitions of Smith and the SBDC do not distinguish between the formal or informal sector. It is assumed that both Smith and the SBDC intended their respective definitions to be applicable to both the formal and informal business sectors. The NMC acknowledged the difference between the two business sectors and formulated a formal definition and a simplified definition which the authors believe should be applied to the informal sector. The definition of the so-called micro businesses formulated by the SBAB also makes reference to the informal sector.

Small business definitions are formulated according to quantitative and qualitative criteria as demonstrated by Smith, the SBDC, the SBAB, and the NMC. Table 4 summarizes the qualitative descriptions and Table 5 the quantitative criteria as perceived by Smith, the SBDC, the SBAB, and the NMC.

\section{Table 4 Qualitative description for a small business}

\begin{tabular}{lcccc}
\hline & SBDCSBAB & NMC & SMITH \\
\hline Privately and independently owned & + & + & + & + \\
Owners are the entrepreneurs & + & - & + & + \\
Simple organization structure & + & - & + & - \\
Owners supply capital & + & - & + & - \\
Small influence on market & - & - & + & - \\
Owners share in the profits & - & - & + & - \\
\hline$+=$ Included in definition; & & & & \\
\hline
\end{tabular}

$+=$ Included in definition; $-=$ Not included in definition 
Table 5 Quantitative guidelines for small business

\begin{tabular}{lcccc}
\hline & SBDCSBAB & NMC & SMITH \\
\hline Definite number of employees & + & + & + & + \\
Definite value of assets & + & + & - & + \\
Definite turnover & + & + & + & + \\
Number of branches & - & + & - & + \\
\hline
\end{tabular}

$+=$ Included in definition; $-=$ Not included in definition

Table 4 and 5 reveals that the definitions suggested by Smith and these organizations are closely related.

All four definitions make use of quantitative guidelines according to specific business sectors. Table 6 sets out the quantitative guidelines for maximum annual turnover and maximum number of employees. Table 5 shows that the SBDC, SBAB, and Smith used value of assets to define a small business. Smith (1978: 46) stipulated a maximum of R500 000 in 1978; the SBDC (1984: 9) stipulated a maximum of R750 000 (excluding land and buildings) in 1984; whilst the SBAB at present stipulates a maximum of $R 1,0$ million (land and buildings excluded).

The results of this survey suggest that, in terms of an important qualitative dimension, the respondents' definition of small business corresponds to some extent with the definitions of the NMC, SBDC, SBAB and Smith, as discussed. Reference can be made to the qualitative criteria of 'privately and independently owned, managed and operated', which is similar to the criterion of independent ownership of the NMC, SBDC, SBAB, and Smith.

The respondents' definition of small business and the definition of the NMC differ quantitatively, however. Nearly $30 \%$ of the respondents stated that the maximum number of employees a business could have and still be termed 'small' could be more than 50 employees, while the definition of the NMC stipulates 'not more than 50 employees'. When these results are compared to the SBDC, NMC, (formal) SBAB, and Smith's definitions the results are comparable with these definitions. It should, however, be mentioned that the respondents state that as a result of the wide differences in the nature of the activities of the various economic sectors, the guidelines for employment of the various sectors will also differ, which is in line with the SBDC, NMC (formal), SBAB, and Smith's definitions.

Regarding turnover restriction, nearly $30 \%$ of the respondents stated that a business with an annual turnover of more than R1 million would still be designated a small business. The upper limit included in the guidelines of the SBDC, NMC (formal), SBAB, and Smith also varies, depending on the various business sectors, when an individualized description of the small business sector is given.

Although pinpointing differences in definition is interesting, it does not imply that one or other party is at fault. Nor does the finding that 'significant' differences in definition do exist imply that there are accurate or inaccurate perceptions. Rather, such differences merely illucidate the complexity of formulating a universally accepted definition and the lack of consensus as to a general definition of small business. It should also be pointed out that the upper limit of quantitative criteria such as turnover and assets is subject to change as it needs to be adapted to economic circumstances. Smith's definition, for example, has been constantly changed by researchers at the SBAB to keep pace with inflationary factors.

As far as quantitative guidelines such as turnover and employees are concerned, a number of respondents pointed out that quantitative guidelines should be treated with care and that the quantitative criteria should be specified in terms of the type of business that is

Table 6 Quantitative guidelines for small business per business sector

\begin{tabular}{|c|c|c|c|c|c|c|c|c|}
\hline \multirow[b]{2}{*}{ Business sector } & \multicolumn{4}{|c|}{ Annual turnover (gross income) } & \multicolumn{4}{|c|}{ Maximum number of employees } \\
\hline & SBCD & SBAB & NMC & SMITH & SBCD & SBAB & NMC & SMITH \\
\hline Mining & R1M & R1M & R1M & * & 100 & 100 & 100 & 100 \\
\hline Manufacturing/Industries & R1M & $\mathbf{R} 2 \mathbf{M}$ & R1M & R1M & 50 & 100 & 50 & 100 \\
\hline Construction & R1M & R5M & R1M & - & 50 & 100 & 50 & 100 \\
\hline Wholesalers & $\mathbf{R} 1 \mathbf{M}$ & R5M & R5M & R5M & 50 & 100 & 50 & 100 \\
\hline Motor trade (exclude fuel) & $\mathbf{R} 1 \mathbf{M}$ & $\mathbf{R} 3 \mathbf{M}$ & R1M & $\mathbf{R} 1 \mathbf{M}$ & - & 100 & 20 & 100 \\
\hline General dealer & RiM & R3M & R1M & - & - & 100 & 20 & 100 \\
\hline Supermarkets & $\mathbf{R} 3 \mathbf{M}$ & R3M & R3M & $\mathbf{R} 3 \mathbf{M}$ & - & 100 & 20 & 100 \\
\hline Speciality shop & RiM & R1M & R1M & R1M & - & 100 & 20 & 100 \\
\hline Accommodation and catering & $0,5 \mathrm{M}$ & R1M & $0,5 \mathrm{M}$ & - & 30 & 100 & 20 & 100 \\
\hline Liquor trade & R3M & R3M & R3M & - & - & 100 & 20 & 100 \\
\hline Service business & $0,5 \mathrm{M}$ & $0,5 \mathrm{M}$ & R1M & $\mathbf{R} 1 \mathbf{M}$ & 20 & 100 & 30 & 100 \\
\hline
\end{tabular}

The SBDC and NMC annual turnover (gross income) is as applicable in 1984 and Smith's definition in 1978 stipulated the maximum turnover for all small businesses should be R1M, but in 1980 Smith (1980: 2) adjusted the figures to account for business sectors (the 1980 turnovers are shown in Table 6). Smith and the SBAB stipulated a maximum number of employees of $\mathbf{1 0 0}$ for all types of small businesses 
operated. The SBDC (1984: 9) noted that quantitative criteria cannot be applied with 'absolute rigidity,' but should be seen as flexible guidelines in order to obtain a perception of the relative size of the business. This is also the viewpoint of the SBAB. In this respect the SBAB suggested the following criteria as far as annual turnover is concerned:

general dealers - R3 million

liquor stores - R3 million

services - R500 000

restaurants $-\mathrm{R} 1$ million

speciality shops - RI million

supermarkets - R3 million

the motor trade - R3 million

wholesale trading - R5 million

construction - R5 million

manufacturing $-\mathrm{R} 2$ million

mining - R1 million.

This suggestion coincides with the SBDC and NMC turnover figures, if 1984 figures are adjusted for inflation.

\section{Conclusion}

In the absence of a formal generally accepted definition of a small business in southern Africa, it appears as if institutions involved in training and advisory services to the small business sector have developed their own definitions. Although the various definitions differ to some extent, there are 'common dimensions'. These dimensions relate to qualitative as well as quantitative aspects.

Of importance is the phenomenon of the presence of the informal business sector in southern Africa. This sector plays an important role in creating employment. Businesses in this sector are predominantly small and a First World definition of a small business may, although it includes this sector, not be applicable to this type of business. One of the respondents in the survey sample reported the results in Table 7 from a survey conducted in Kwazulu in 1986 in respect of quantitative criteria.

However, a survey in the construction, mining and wholesale businesses could reveal different results.

The Sullivan Task Group 7 (Amey 1986: 12) formulated a definition for black small business in terms of the informal sector. This definition reads as follows: 'A richly diverse and varied sector, (which) encompasses family hawker types, mother and three children selling

Table 7 Average number of employees according to type of business (data supplied by respondent)

\begin{tabular}{|c|c|c|c|c|c|}
\hline Type of business & $\begin{array}{c}\text { General } \\
\text { dealer }\end{array}$ & Butchery & $\begin{array}{l}\text { Restau- } \\
\text { rant }\end{array}$ & $\begin{array}{l}\text { Bottle } \\
\text { store }\end{array}$ & Garage \\
\hline Number of businesses & & & - & & \\
\hline surveyed & 146 & 16 & 25 & 10 & 6 \\
\hline $\begin{array}{l}\text { Average number of } \\
\text { employees }\end{array}$ & 4 & 4 & 3 & 4 & 5 \\
\hline
\end{tabular}

fruit at a bus stop, through the one-man repair service, the small group involved in backyard manufacturing, and beyond that up to $\mathbf{1 0}$ or more people involved in a business with a turnover of R100 000 per annum or more'.

This definition coincides with the survey results in Kwazulu.

Although no specific definition is suggested here, it is hoped that the findings presented and the interpretations thereof will stimulate and encourage efforts to develop a simple, useful, and widely accepted definition of small business in southern Africa. However, the definition that does evolve should incorporate the philosophy of the free market system and allow for the peculiar circumstances of an economy with a large component of under-developed people. Ideally, a specific definition should be formulated for the informal sector.

\section{References}

Amey, R.L. 1986. An approach to providing venture capital to the informal black manufacturing sector. Johannesburg: Sullivan Task Group 7. Small business committee, p 12.

Bulloch, J.F. \& Hertz, L. 1982. An international acceptable small business definition. Paper delivered at the International Small Business Congress, Madrid.

De Villiers, D.J. Speech delivered by Minister of Trade and Industry at the announcement of the Council for Small Business. 25 November 1986.

Moolman, P.L. 1987. Small Business Management. In: Applied Business Economics. An introductory survey. (Ed.) P.G. du Plessis. Educational publishers. Pretoria.

Moolman, P.L. \& Pretorius, J. 1987. Evaluation of the RIDP as an element of the Regional Development Policy with special reference to the role of small business.

Potchefstroom. Confidential report to the Development Bank of Southern Africa. October 1987, 2-3.

National Manpower Commission. 1984. Report on an Investigation into the Small Business Sector in the Republic of South Africa, with specific reference to the factors that may retard the growth and development thereof. Pretoria: Report 1/84, 6-9.

President's Council. 1985. Report of the Committee for Economic affairs on a Strategy for Small Business Development and for Deregulation. Pretoria: Government Printer.

Small Business Development Corporation, 1984. Small Business Rebate Scheme Guidelines, 7-9.

Small Business Development Corporation, 1987. Small Business Training Directory. Johannesburg.

Small Business Rebate Scheme. 1984. Guidelines, 7-9. Smith, J.G. 1978. Die problematiek van die klein ondernemer met spesiale verwysing na konsultasiedienste as metode tot hulpverlening van klein sakeondernemings. Unpublished DBA Thesis. Potchefstroomse Universiteit vir Christelike Hoër Onderwys. Potchefstroom, p. 46.

Smith, J.G. 1980. 'n Definisie vir klein sakeondernemings. An unpublished explanation. Potchefstroom: Small Business Advisory Bureau. Potchefstroom, p. 2. 